\title{
Adsorption study on municipal solid waste leachate using Moringa oleifera seed
}

\author{
D. Sivakumar
}

Received: 26 May 2011/Revised: 30 October 2011/Accepted: 1 February 2012/Published online: 14 July 2012 (C) CEERS, IAU 2012

\begin{abstract}
Effects of initial concentrations of Moringa oleifera seed coagulant for removing Chemical Oxygen Demand and Total Dissolved Solids from municipal solid waste leachate have been evaluated at an optimum $\mathrm{pH}$ of 7 and temperature of $318 \mathrm{~K}$. The kinetic data obtained from the experiments were fitted to the pseudo first-order, pseudo second-order, Elovich and intraparticle diffusion models. Based on a regression coefficient $\left(R^{2}\right)$, the equilibrium (kinetic) data were best fitted with the Elovich model ( $R^{2}=0.993$ for Chemical Oxygen Demand and $R^{2}=0.996$ for Total Dissolved Solids) than that of other models. The results of the kinetic models study indicated that the adsorption capacity of $M$. oleifera seed as a coagulant for removing Chemical Oxygen Demand and Total Dissolved Solids in a leachate increased up to $100 \mathrm{mg} \mathrm{L}^{-1}$, beyond which the adsorption capacity got reduced. Finally, the present study concluded that $M$. oleifera seed coagulant could be employed effectively for the removal of Chemical Oxygen Demand and Total Dissolved Solids in a municipal solid waste leachate.
\end{abstract}

Keywords Chemical Oxygen Demand - Kinetic models · Regression analysis · Total Dissolved Solids

\section{Introduction}

Municipal solid wastes (MSWs) are unavoidable products, disposed by various human activities. The solid wastes are

\footnotetext{
D. Sivakumar $(\square)$

Vel Tech High Tech Dr. Rangarajan Dr. Sakunthala Engineering College, Affiliated to Anna University Chennai,

No. 60, Avadi-Vel Tech Road, Avadi,

Chennai 600 062, Tamil Nadu, India

e-mail: sivakumar.ijest@gmail.com
}

categorized primarily based on the place of generation viz., urban, rural and industrial areas (Tchobanoglous et al. 1993a). Proper disposals of these solid wastes are imperative. The most common method of disposal of solid wastes is by land filling (Mishra and Mani 1993; Tchobanoglous et al. 1993a, b). The composition of MSWs depends on industrialization, urbanization, waste management and local conditions. Incorrectly secured and improperly operated MSWs landfills pose a serious threat to the environment, mainly to the surface water and groundwater (Demetracopoulos et al. 1984; Karfiatis and Demetracopoulos 1984). The scale of this threat depends on the quantity, quality and composition of the leachate and the distance of a landfill from water sources (Słomczyńska and Słomczyński 2004). MSW leachate is considered as highly concentrated complex effluent, which may contain dissolved mineral and organic compounds (humic substances, fatty acids and aromatic compounds), inorganic macro components, heavy metals, xenobiotic organic compounds and many other hazardous chemicals (Peter et al. 2002; Tchobanoglous et al. 1993a, b). The generated amount of leachate depends on initial water content of MSWs and on the storage or disposal conditions such as temperature, humidity and ventilation (Sivakumar and Pushpakaran 2010a, b).

Thus, knowledge of the quantity, quality and composition of leachate is necessary when designing the treatment facilities and it is important in determining raw leachate pollution effect on the environment (Słomczyńska and Słomczyński 2004). Due to simplicity and cost-effectiveness, the adsorption method has been widely used (Babel and Kurniawan 2003; Ho and McKay 1998) to control the various pollutants from the water and wastewater. Exploration of good low-cost and non-conventional adsorbents may contribute to the sustainability of the environment and 
offer promising benefits for the commercial purpose in a future. The costs of the activated carbon prepared from biomaterials are negligible when compared with the cost of commercial activated carbon. Some of the activated carbons (prepared from agro-based wastes) used to treat the industrial wastewater in the recent past are corncob, groundnut husk, rice husk, tea leaves carbon, saw dust (Nigam and Rama 2002) eucalyptus bark (Aravind and Prem 2003) and agricultural wastes (Adinata et al. 2007).

The use of natural materials of plant origin to purify water and wastewater is not a new idea. This study mainly pays attention to Moringa oleifera, a natural material of plant origin, used to purify municipal solid waste leachate. M. oleifera belongs to the family Moringaceae. M. oleifera originates in India and spread throughout the tropics from Northeastern Pakistan (from $33^{\circ} \mathrm{N}$ to $73^{\circ} \mathrm{E}$ ) to Northern West Bengal State in India and Northeastern Bangladesh. It can grow at elevations from sea level to $1,400 \mathrm{~m}$ (Ramachandran et al. 1980). It is cultivated in most parts of Pakistan, India, and Nepal, as well as in Afghanistan, Bangladesh Sri Lanka, Southeast Asia, West Asia, the Arabian Peninsula, East and West Africa, throughout the West Indies and Southern Florida, in Central and South America from Mexico to Peru, as well as in Brazil and Paraguay (Jahn et al. 1986). M. oleifera is a slender softwood tree that branches freely and can grow extremely fast to a height of $10 \mathrm{~m}$. It will survive in a temperature range from 25 to $40{ }^{\circ} \mathrm{C}$, but has been known to tolerate temperature of $48{ }^{\circ} \mathrm{C}$ and light frosts. M. oleifera grows neutral to slightly acidic soils and grows best in well-drained loam to clay-loam. It tolerates clay soils but does not grow well in waterlogged condition.

Among other plant materials, powder form of $M$. oleifera seed has been proven to be one of the most effective and viable replacements of various chemical coagulants (Nwaiwu and Lingmu 2011; Sanchez-Martin et al. 2010; Amagloh and Benang 2009; Ndabigengesere and Narasiah 1998a; Jahn 1988) for treating water (Muyibi et al. 2001; Muyibi and Evison 1995a, b) and wastewater (Daniyan et al. 2011; Muyibi et al. 2002; Ndabigengesere and Narasiah 1998b; Ndabigengesere et al. 1995; Olsen 1987). Further, the powder form of M. oleifera is used to remove the heavy metals and surfactants (Beltrán- Heredia and Sánchez-Martín 2008, 2009) from water and wastewater. The use of M. oleifera seed powder has an added advantage over the chemical treatment of water and wastewater, as it is biological and edible. The powder joins with the materials and contaminants in the aqueous solutions and sinks to the bottom (Varsha and Punita 2010) of any treatment units. This treatment also removes $90-99 \%$ of bacteria contained in water (Katayon et al. 2005). High-quality activated carbon prepared from the waste husks of $M$. oleifera (Miquel and Wendy 2010; Pollard et al. 1995) is used to purify the water and $M$. oleifera pods are efficient in absorbing organic pollutants and pesticides (Akhtar et al. 2007a, b). In addition, dehusked M. oleifera press cake is efficient in the removal of hydrophobic organic pollutants from water (Boucher et al. 2007) and the extracted part of $M$. oleifera seeds prevents the growth of coliforms, sodomonas and aeroginosen and as a result, reduces the requirement for disinfection (Yarahmadi et al. 2009; Caceres 1991).

Thus, the aim of present study was to investigate the effect of initial concentration of $M$. oleifera seed coagulant for removing Chemical Oxygen Demand (COD) and Total Dissolved Solids (TDS) in a municipal solid waste leachate. Further, the experimental data were fitted to various kinetic models like pseudo first-order, pseudo secondorder, Elovich and intraparticle diffusion models for determining the suitability of $M$. oleifera seed as a coagulant in removing COD and TDS from a municipal solid waste leachate. All experiments were conducted in the Environmental Engineering Laboratory, Department of Civil Engineering, Easwari Engineering College, Tamil Nadu, India, during December 2010.

\section{Materials and methods}

Moringa oleifera seeds were purchased from the local market, Thanjavur, Tamil Nadu, India. The chemical properties of $M$. oleifera seed are listed in Table 1. The seeds were dried and dehusked mechanically by removing the seed wings and coat. The white seed kernels were pulverized and sieved through a $0.75-\mathrm{mm}$ sieve. $100 \mathrm{mg}$ of powdered form of $M$. oleifera seed was mixed with 11 of distilled water, stirred with a stirrer for a period of $30 \mathrm{~min}$ and finally the stirred solution kept for a period of $24 \mathrm{~h}$ to generate a coagulant. After a period of $24 \mathrm{~h}$, the required amount of coagulant was taken for conducting the experiments, and the remaining quantity was kept in the refrigerator at a temperature of $278 \mathrm{~K}$. This method was used to avoid the decomposition of coagulant, because the M. oleifera seed coagulant is an agro-based product. Recent study has also proven that extracted form of active coagulant from the $M$. oleifera seeds are unstable and normally deteriorate when stored under room conditions and cause decrease in its coagulation property (Saulawa et al. 2011).

The total nine solid waste samples of $1 \mathrm{~kg}$ each were collected from a center (three samples), boundary (three samples) and between center and boundary (three samples) of Thanjavur Municipality Dumping Yard, Tamil Nadu, 
Table 1 The chemical properties of Moringa oleifera seed

\begin{tabular}{llr}
\hline S. No. & Properties of Moringa oleifera seed & Values \\
\hline 1 & Proximate properties & \\
& Moisture (\%) & 71.3 \\
& Ash (\%) & 2.3 \\
Carbohydrate (\%) & 3.7 \\
& Fiber (\%) & 6.7 \\
& Protein (\%) & 12.8 \\
& Fat (\%) & 3.2 \\
& Mineral properties & \\
& Calcium (mg) & 43.5 \\
& Magnesium (mg) & 13.6 \\
& Potasium (mg) & 186.2 \\
& Phosporous (mg) & 138.5 \\
& Iron (mg) & 16.5 \\
& Sulfate (mg) & 98.2 \\
\hline
\end{tabular}

India. The age of the solid waste was known to be 6 months (data provided by the authority of Thanjavur Municipality). The average compositions of three samples (replicates) collected from each center, boundary, between a center and boundary, respectively, were determined and are presented in Table 2. Further, overall average compositions of solid waste at Thanjavur Municipality Dumping Yard were determined, and the compositions are presented (Table 2) in percentage. (i.e., reported as a weight basisratio of weight of each component in the sample to the total weight of the sample).

The solid waste collected from entire Thanjavur District was dumped into the Thanjavur Municipality Dumping Yard (landfill). The solid waste in a landfill was compacted by roller and the mass density of compacted solid waste was found to be $2,560 \mathrm{~kg} / \mathrm{m}^{3}$ (the mass density of solid waste was calculated based on standard procedure stipulated by Gopal and Rao 2009). There was no natural drainage occurred at the landfill site, results, unable to collect a leachate from landfill directly. Thus, it is necessary to generate a leachate in the laboratory for further study. Before applying the distilled water over solid waste to obtain a leachate, solid waste collected from Thanjavur Municipality Dumping Yard was compacted into the container of size $0.3 \times 0.3 \times 0.5 \mathrm{~m}$ (length $\times$ breadth $\times$ height) by compacting device. In order to simulate the field condition, a mass density of solid waste in the container was maintained at $2,560 \mathrm{~kg} \mathrm{~m}^{-3}$. After compaction, distilled water was applied over the solid waste directly to obtain an experimental fluid (leachate), and its quality was analyzed using a standard procedure (APPA, AWWA and WEF 2005). The present study mainly focused on reducing the COD and TDS concentrations in a leachate using $M$. oleifera seed as a coagulant at various initial concentrations. Since the age of solid waste is 6 months, the initial concentration of COD and TDS in an experimental leachate was found only to be 12,435 and $5,485 \mathrm{mg} \mathrm{L}^{-1}$, respectively.

The previous studies discovered that the laboratory test results on untreated grab leachate samples showed high concentration of TDS $\left(734 \mathrm{mg} \mathrm{L}^{-1}\right)$ and COD (1,631 $\mathrm{mg} \mathrm{L}^{-1}$ ) (Azim et al. 2011). The COD concentration in a landfill leachate varied from 110 to $300 \mathrm{mg} \mathrm{L}^{-1}$ (Noor et al. 2011). TDS and COD concentration in a landfill leachate of Benin-City, Edo State, Nigeria was found to be $32,192 \pm 563.78$ and $91.47 \pm 1,30 \mathrm{mg} \mathrm{L}^{-1}$,
Table 2 Compositions of solid waste from Thanjavur Municipality Dumping Yard

\footnotetext{
* Components were identified by manually (eye validation)

** Average compositions value of three samples collected from each place

*** Overall average composition of solid waste from Thanjavur Municipality Dumping Yard
}

\begin{tabular}{|c|c|c|c|c|}
\hline \multirow[t]{2}{*}{ Components* } & \multicolumn{4}{|l|}{ Places } \\
\hline & $\begin{array}{l}\text { Center** } \\
(\%)\end{array}$ & $\begin{array}{l}\text { Boundary** } \\
(\%)\end{array}$ & $\begin{array}{l}\text { Between center and } \\
\text { boundary** } \\
(\%)\end{array}$ & $\begin{array}{l}\text { Average } * * * \\
(\%)\end{array}$ \\
\hline Polythene milk sachets & 11.4 & 10.9 & 10.8 & 11.4 \\
\hline Vegetable food wastes (organic) & 56.8 & 54.5 & 56.1 & 55.8 \\
\hline Paper (news paper, card boards, etc.) & 11.7 & 12.7 & 12.2 & 12.2 \\
\hline Wood chips (plant, carpentry) & 7.4 & 8.7 & 8.8 & 8.3 \\
\hline Plastics (sheets, solid, bags, etc.) & 3.8 & 4.3 & 4.2 & 4.1 \\
\hline Glass & 1.9 & 1.6 & 1.6 & 1.7 \\
\hline $\begin{array}{l}\text { Cotton wastes (thread, cloth, sanitary } \\
\text { napkins, etc.) }\end{array}$ & 1.4 & 1.8 & 1.3 & 1.5 \\
\hline $\begin{array}{l}\text { Metals (workshop waste, stainless } \\
\text { steel, pins, etc.) }\end{array}$ & 1.5 & 1.6 & 1.2 & 1.3 \\
\hline Leather and rubber & 1.2 & 1.3 & 1.4 & 1.2 \\
\hline Others such as battery & 2.9 & 2.6 & 2.4 & 2.5 \\
\hline Total & 100.0 & 100.0 & 100.0 & 100.0 \\
\hline
\end{tabular}


respectively (Aiyesanmi and Imoisi 2011). Amir and Ali 2011 studied about the characteristics of solid waste landfill leachate for four different landfills. The results showed that TDS and COD concentration varied from 1,123 to $17,500 \mathrm{mg} \mathrm{L}^{-1}$ and from 250 to $4,852 \mathrm{mg} \mathrm{L}^{-1}$, respectively at Shahrood's landfill. Further, TDS and COD concentration in Turkey's landfill varied from 209 to 4,418 $\mathrm{mg} \mathrm{L}^{-1}$ and 250 to $4,852 \mathrm{mg} \mathrm{L}^{-1}$ respectively (Amir and Ali 2011). The change in temperature, climatic condition, soil used for land filling, organic and inorganic materials in the solid waste, age of the solid waste, other characteristics of solid waste and method of land filling are the main factors for changing the COD and TDS concentration in different landfills.

Leachate was filled in six glass beakers of one-liter capacity and placed in the Phipps and Bird jar test apparatus, which was used for evaluating and optimizing the coagulation process by $M$. oleifera seed coagulant. Adsorption of COD and TDS by M. oleifera seed coagulant was influenced by $\mathrm{pH}$, temperature (Oluduro and Aderiye 2007; Katayon et al. 2004) and storage conditions (Katayon 2004, 2006a, b). To evaluate and optimize the coagulation process, experiments were conducted at different $\mathrm{pH}(4,5$, $6,7,8$ and 9), different temperature $(300,306,312,318$, 324 and $330 \mathrm{~K}$ ) and different concentration (75 and $100 \mathrm{mg} \mathrm{L}^{-1}$ ) with rapid mixing rotational speed of $100 \mathrm{rpm}$, slow mixing rotational speed of $20 \mathrm{rpm}$ and settlement period of $60 \mathrm{~min}$. The recommended settling time is 1 to $2 \mathrm{~h}$ for all the particles and contaminants to settle at the bottom of the storage container using $\mathrm{M}$. oleifera seed (Nwaiwu and Lingmu 2011). Thus, after a settlement period of $60 \mathrm{~min}$ (in this study), the concentration of COD and TDS in a supernatant leachate was analyzed as per standard procedure given by APPA, AWWA and WEF (2005).

Further, the effects of M. oleifera seed coagulant for reducing COD and TDS in a solid waste leachate, batch adsorption tests were carried out in $100 \mathrm{~mL}$ flasks, immersed in a thermostatic shake water bath (to maintain the temperature). The agitation speed for the flasks was keeping at a constant speed of $100 \mathrm{rpm}$. The flasks wew shaken for the adsorption periods varying from 20 to $160 \mathrm{~min}$. Batch experiments were carried out at different initial concentrations 20,40, 60, 80, 100 and $120 \mathrm{mg} \mathrm{L}^{-1}$ at neutral $\mathrm{pH}$ (obtained from Figs. 1, 2) and at a temperature of $318 \mathrm{~K}$ (obtained from Figs. 3, 4). After various adsorption periods $(20,40,60,80,100$, 120,140 and $160 \mathrm{~min}$ ), the supernatant leachate in flasks was centrifuged at $2,500 \mathrm{rpm}$ for $15 \mathrm{~min}$. The concentration of COD and TDS in a supernatant leachate was analyzed as per the standard prescribed by APPA, AWWA and WEF (2005).
Using a mass balance, the concentration of COD and TDS at different adsorption periods by M. oleifera seed coagulant were calculated as

$q_{t}=\frac{\left(C_{0}-C_{t}\right) V}{M}$

in which, $q_{t}$ is the amount of COD and TDS adsorbed by the $M$. oleifera seed coagulant at time ' $t$ ', $C_{0}$ is the initial concentration of COD and TDS, $C_{t}$ is the aqueous phase concentration of COD and TDS at time ' $t$ ', ' $V$ ' is the volume of the aqueous phase and ' $M$ ' is the weight of M. oleifera seed powder.

Many kinetic models propose to elucidate the mechanism of solute adsorption and potential rate controlling step. These include pseudo-first order, pseudo-second order, Elovich and intraparticle diffusion equations (Parimalam et al. 2011; Igwe and Abia 2006; Ho and McKay 1998). The rate and mechanism of adsorption were controlled by various factors like physical and/or chemical properties of adsorbents, ambient temperature and solution pH (Oluduro and Aderiye 2007; Katayon et al. 2004). These four kinetic models are useful for the design and optimization of effluent-treatment process. Hence, the experimental data obtained from batch studies were fitted to the above four kinetic models for determining the suitability of $M$. oleifera seed coagulant for removing COD and TDS in a leachate.

The pseudo-first order equation of Lagergren is generally expressed as

$\log \left(q_{e}-q_{t}\right)=\log q_{e}-\frac{k_{1}}{2.303} t$

in which, $q_{e}$ is the sorption capacity at equilibrium $(\mathrm{mg} / \mathrm{g})$, $q_{t}$ is the sorption capacity at time ' $t$ ' $(\mathrm{mg} / \mathrm{g}), k_{1}$ is the first-order rate constant $\left(\mathrm{min}^{-1}\right)$ and ' $t$ ' is time (min). Hence, a linear trace is expected between the two parameters, $\log \left(q_{e}-q_{t}\right)$ and ' $t$ ', provided the adsorption follows first order kinetics. The values of $k_{1}$ and $q_{e}$ can be determined from the slope and intercept.

The pseudo-second order kinetic rate equation is expressed as

$\frac{\mathrm{t}}{q_{t}}=\frac{1}{k_{2} q_{e}^{2}}+\frac{1}{q_{e}} t$

in which, $K_{2}$ is the second-order rate constant (mg g ${ }^{-1} \min ^{-1}$ ). A plot of $t / q_{t}$ and ' $t$ ' should give a linear relationship if the adsorption follows second order. $q_{e}$ and $k_{2}$ can be calculated from the slope and intercept of the plot.

The Elovich equation is expressed as

$q_{t}=\frac{\ln (\alpha \beta)}{\beta}+\frac{\ln (t)}{\beta}$ 
in which, ' $\alpha$ ' is the initial sorption rate and ' $\beta$ ' is the desorption constant. A plot of $q_{t}$ versus $\ln (t)$ should give a linear relationship if the Elovich equation is applicable with a slope of $(1 / \beta)$ and an intercept of $(\ln (\alpha \beta) / \beta)$.

The intraparticle diffusion equation is expressed as

$q_{t}=k_{p} t^{1 / 2}+C$

in which, $k_{\mathrm{p}}$ is the intraparticle diffusion constant.

\section{Results and discussion}

Effects of $\mathrm{pH}$ on COD and TDS removal

The $\mathrm{pH}$ is an important parameter for determining the adsorption capacity because it affects the solubility and degree of ionization of the adsorbate (Adelaja et al. 2011). Experiments were carried out at different initial $\mathrm{pH}(\mathrm{pH}$ ranges from 4 to 9 with an increment of 1) to investigate the effects of initial $\mathrm{pH}$ on COD and TDS removal in a solid waste leachate at a concentration of $75 \mathrm{mg} \mathrm{L}^{-1}$ (Fig. 1) and $100 \mathrm{mg} \mathrm{L}^{-1}$ (Fig. 2), respectively. From Figs. 1 and 2, it may be observed that till $\mathrm{pH}$ value reaches 7 , the removal percentage of COD and TDS increased, beyond which removal percentage got decreased. However, a significant change in percentage removal has observed between the $\mathrm{pH}$ value 6 and 8 .

At low $\mathrm{pH}$, hydrogen ions in the mixture were not allowing the ions to adhere with the binding sites of adsorbents. At high $\mathrm{pH}$, a leachate becomes basic and amino acids present in the protein of M. oleifera would accept a proton from a leachate and released more hydroxyl groups making the solution more basic (Daniyan et al. 2011; Amagloh and Benang 2009); as a result, ions were

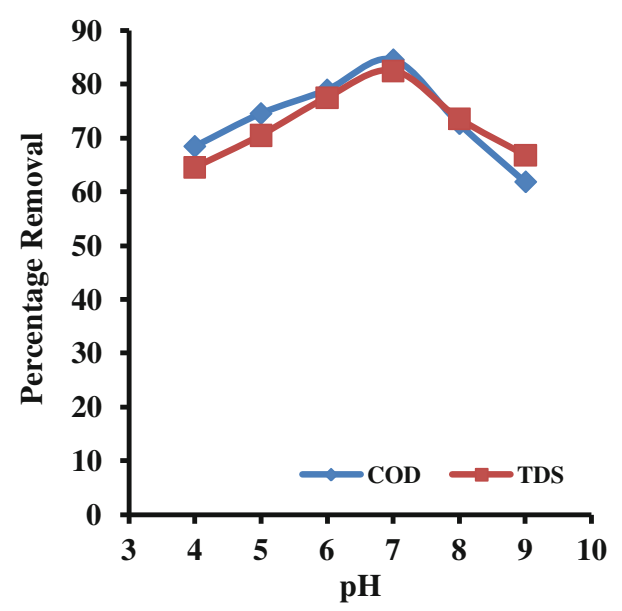

Fig. 1 Effects of $\mathrm{pH}$ on COD and TDS removal at a concentration of $75 \mathrm{mg} \mathrm{L}^{-1}$

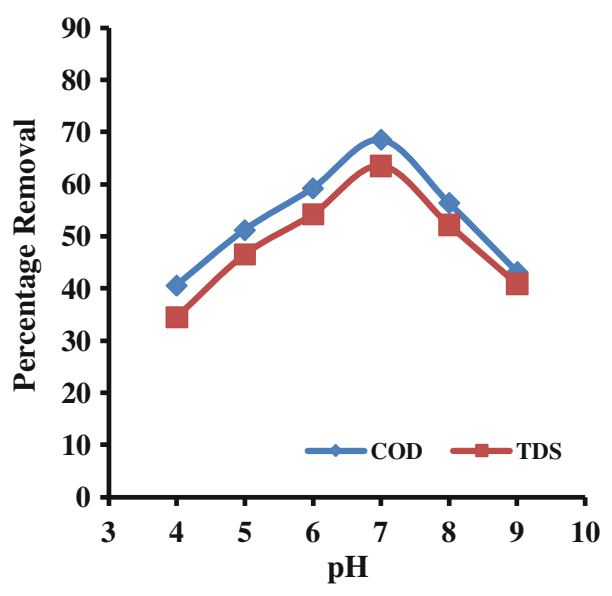

Fig. 2 Effect of $\mathrm{pH}$ on COD and TDS removal at a concentration of $100 \mathrm{mg} \mathrm{L}^{-1}$

not adhering into the binding sites of adsorbents. However, between the $\mathrm{pH}$ value 6 and 8 , more ions were adhering to the binding sites of adsorbents because of neutral nature of leachate. Thus, an optimum $\mathrm{pH}$ value leading to maximum COD and TDS removal percentage was found to be 7 (Figs. 1, 2). From Figs. 1 and 2, it was found that COD and TDS removal percentage by $\mathrm{M}$. Oleifera seed coagulant at an optimum $\mathrm{pH}$ of 7 was 84.5 and $82.5 \%$, respectively, for a concentration of $100 \mathrm{mg} \mathrm{L}^{-1}$ and 68.5 and $63.5 \%$, respectively, for a concentration of $75 \mathrm{mg} \mathrm{L}^{-1}$.

\section{Effects of temperature on COD and TDS removal}

To investigate the effects of temperature on COD and TDS removal using $M$. oleifera seed coagulant, treatment was done at different temperatures viz., 300, 306, 312, 318,324 and $330 \mathrm{~K}$ for a concentration of $75 \mathrm{mg} \mathrm{L}^{-1}$ (Fig. 3) and $100 \mathrm{mg} \mathrm{L}^{-1}$ (Fig. 4), respectively. As similar to $\mathrm{pH}$, from 300 to $318 \mathrm{~K}$ temperature, the diffusion rates of the adsorbate molecules across the external boundary layer are high, yielding more adsorptions of COD and TDS by M. Oleifera seed coagulant (Figs. 3, 4). Beyond $318 \mathrm{~K}$ temperature, less adsorption was observed, because of low diffusion rate of the adsorbate molecules. Furthermore, at low and high temperatures, liberalization of a hydroxyl group from the amino acids presented in the protein of M. oleifera was low (leachate is more acidic condition) and high (leachate is basic condition), respectively. However, at $318 \mathrm{~K}$, liberalization of a hydroxyl group from the amino acids present in the protein of M. oleifera was moderate, which is sufficient to create favorable environment for the ions to adhere to the binding sites of the adsorbents (Daniyan et al. 2011; Amagloh and Benang 2009). Thus, an optimum 


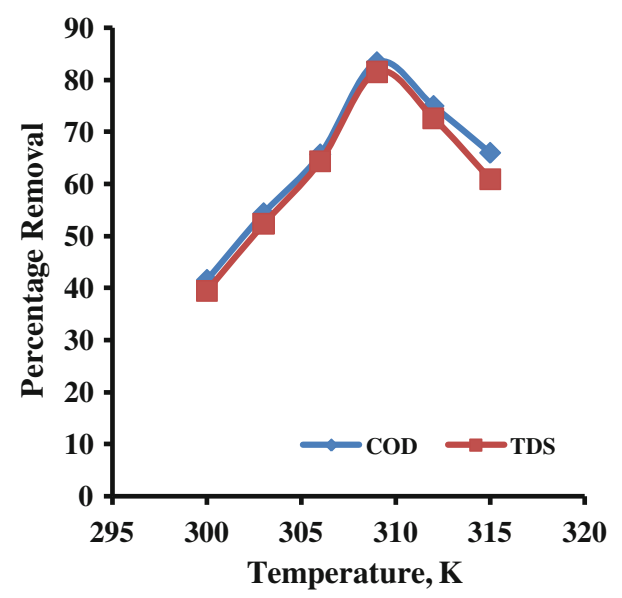

Fig. 3 Effects of temperature on COD and TDS removal at a concentration of $75 \mathrm{mg} \mathrm{L}^{-1}$

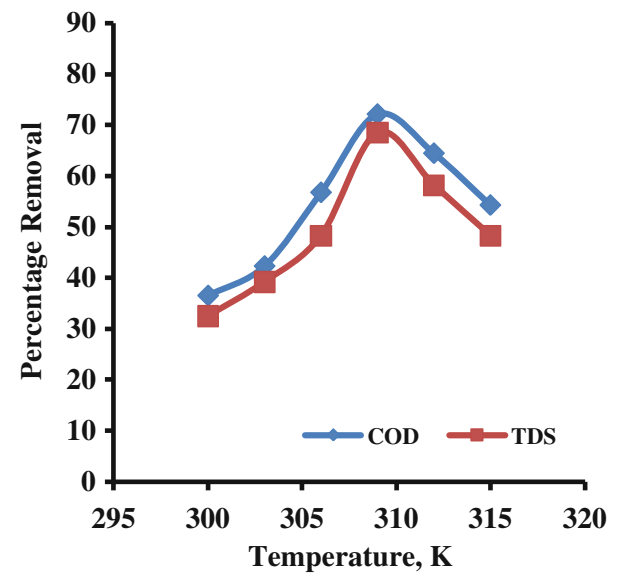

Fig. 4 Effects of temperature on COD and TDS removal at a concentration of $100 \mathrm{mg} \mathrm{L}^{-1}$

temperature leading to maximum COD and TDS removal percentage was found to be $318 \mathrm{~K}$ (Figs. 3, 4). From Figs. 3, 4, it was found that COD and TDS removal percentage by $M$. Oleifera seed coagulant at an optimum temperature of $318 \mathrm{~K}$ was 83.3 and $81.5 \%$, respectively, for a concentration of $100 \mathrm{mg} \mathrm{L}^{-1}$ and 72.2 and $68.5 \%$, respectively, for a concentration of $75 \mathrm{mg} \mathrm{L}^{-1}$.

In order to validate the effects of $\mathrm{pH}$ and temperature on COD and TDS removal in a leachate, experiments have been performed with an optimum $\mathrm{pH}$ value of 7 (Figs. 1, 2) and temperature of $318 \mathrm{~K}$ (Figs. 3, 4). The results obtained at an optimum $\mathrm{pH}(7)$ and temperature $(318 \mathrm{~K})$ showed that maximum COD and TDS removal percentage by $\mathrm{M}$. Oleifera seed coagulant was 84.5 and $82.6 \%$, respectively, for a concentration of $100 \mathrm{mg} \mathrm{L}^{-1}$ and 75.1 and $70.9 \%$, respectively, for a concentration of $75 \mathrm{mg} \mathrm{L}^{-1}$. Hence, kinetic model's study was performed by changing the initial coagulant concentrations at an optimum $\mathrm{pH}$ (7) and temperature $(318 \mathrm{~K})$.

Adsorption kinetics

A study of adsorption kinetics is desirable as it provides information about the mechanism of adsorption, which is important for efficiency of the process (Maximova and Koumanova 2008). The experimental results of adsorption of COD and TDS by M. oleifera seed coagulant at various initial concentrations are shown in Figs. 5 and 6, respectively.

From Fig. 5, it can be observed that adsorption of COD by $M$. oleifera seed coagulant occurred very rapidly within the first $20 \mathrm{~min}$ and equilibrium occurred after $120 \mathrm{~min}$. The same result was also observed for the adsorption of TDS by M. oleifera seed coagulant (Fig. 6). Further, with increased initial concentrations of coagulant from 20 to $120 \mathrm{mg} \mathrm{L}^{-1}$, the adsorption of COD and TDS with M. oleifera coagulant increased. However, higher adsorption capacity of COD and TDS with $M$. oleifera coagulant obtained at $100 \mathrm{mg} \mathrm{L}^{-1}$, because of M. oleifera seed

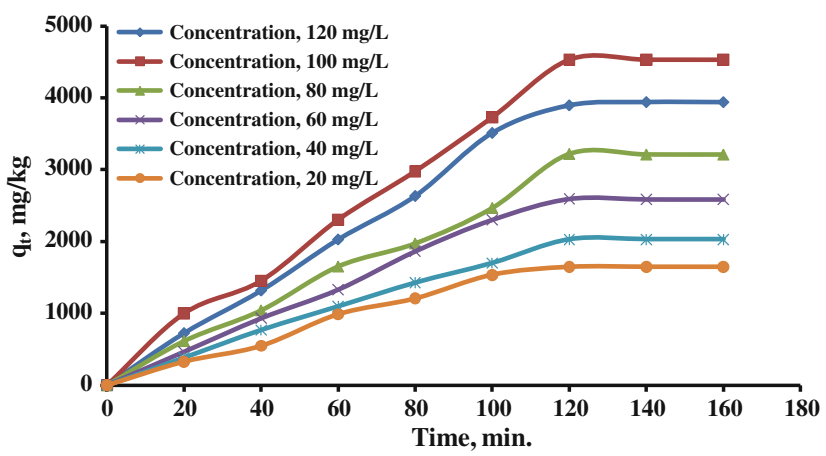

Fig. 5 Effects of Moringa oleifera seed coagulant for removing COD at various initial concentrations

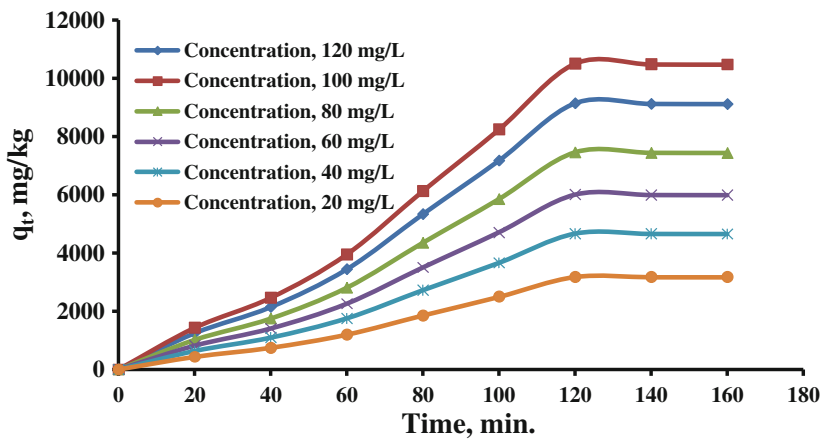

Fig. 6 Effects of Moringa oleifera seed coagulant for removing TDS at various initial concentrations 
Fig. 7 Four kinetic models for COD adsorption removal at various initial concentrations

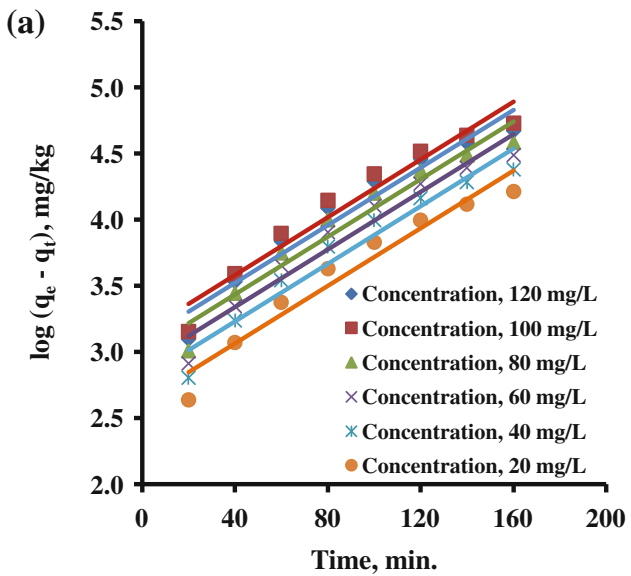

Pseudo-first order kinetic model

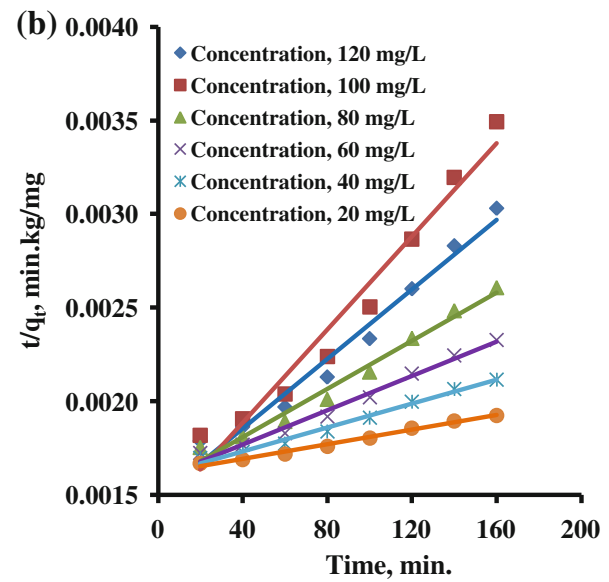

Pseudo-second order kinetic model

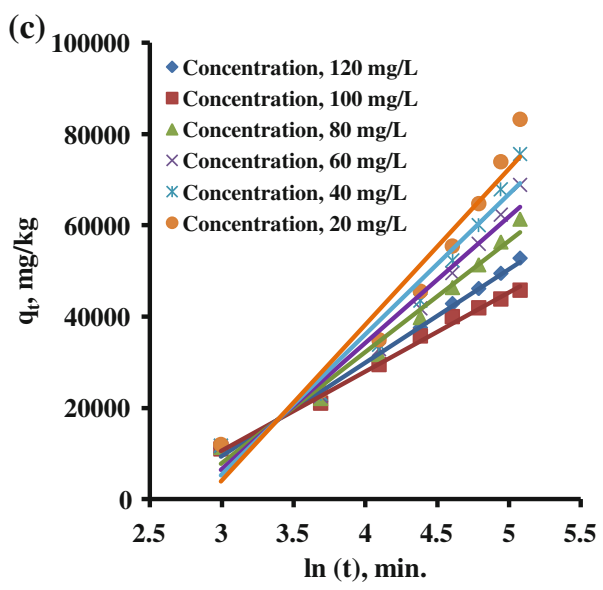

Elovich kinetic model

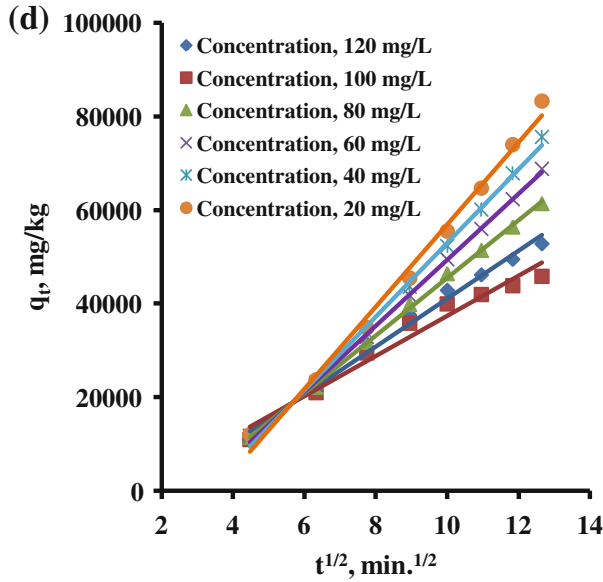

Intraparticle diffusion kinetic model coagulant has more active sites at $100 \mathrm{mg} \mathrm{L}^{-1}$, beyond which the adsorption capacity got reduced (Figs. 5, 6). It may also be found from the aforementioned results that at $120 \mathrm{mg} \mathrm{L}^{-1}$ initial concentration, the $M$. oleifera seed coagulant has more active sites as similar to $100 \mathrm{mg} \mathrm{L}^{-1}$ initial concentrations. However, $120 \mathrm{mg} \mathrm{L}^{-1}$ initial concentration is not sufficient for adsorbing COD and TDS in a leachate, because, a coagulant itself produces more sludge. Thus, an optimum dosage for which the maximum removal of COD and TDS occurred at an initial concentration of $100 \mathrm{mg} \mathrm{L}^{-1}$ (Figs. 5, 6). At a concentration of $100 \mathrm{mg} \mathrm{L}^{-1}$ positively charged water-soluble proteins in a powder form of a $M$. oleifera seed kernel act like magnets and attract the predominantly negatively charged particles in an aqueous solution to form settleable flocs, leading to maximum removal by $M$. oleifera (Matthew et al. 2011).

In order to investigate the consistency, experimental data were fitted with the four kinetic model (pseudo-first order, pseudo-second order, Elovich and intraparticle diffusion) equations. The plots of the four kinetic equations for removing COD and TDS from municipal solid waste leachate using $M$. oleifera seed as a coagulant at various initial concentrations are shown in Figs. 7 and 8, respectively. In order to measure the degree of relationship between two or more variables, the correlation and regression analysis were performed for all parameters.

From Fig. 7a, it may be found that the pseudo first-order rate constant $\mathrm{k}_{1}$ for COD ranges between 0.014 and $0.065 \mathrm{~min}^{-1}$. The correlation coefficient $R^{2}$ found to range from 0.918 to 0.946 . It was found that the values for rate constant $\left(k_{2}\right)$ of pseudo-second order kinetic model for COD decreases from 0.00138 to $0.00161 \mathrm{~kg} \mathrm{mg}^{-1} \mathrm{~min}^{-1}$ (Fig. 7b) and the ' $\beta$ ' value for COD varies between 0.0000324 and 0.0000575 with an increase of the initial concentrations from 20 to $120 \mathrm{mg} \mathrm{L}^{-1}$ (Fig. 7c). The correlation coefficient $R^{2}$ for pseudo-second order model varies from 0.938 to 0.963 and correlation coefficient $R^{2}$ for Elovich kinetic model showed that very high 
Fig. 8 Four kinetic models for TDS adsorption removal at various initial concentrations

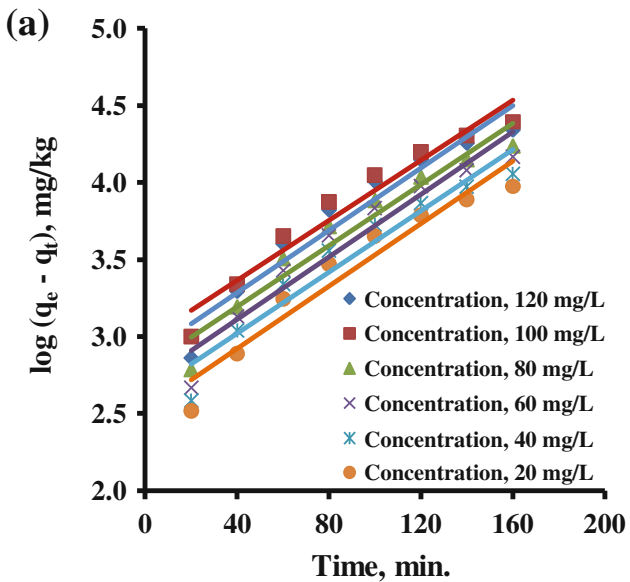

Pseudo-first order kinetic model

(b)

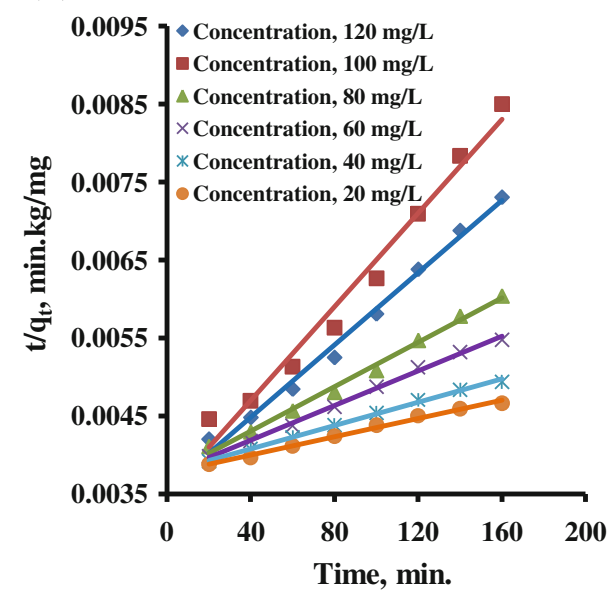

Pseudo-second order kinetic model

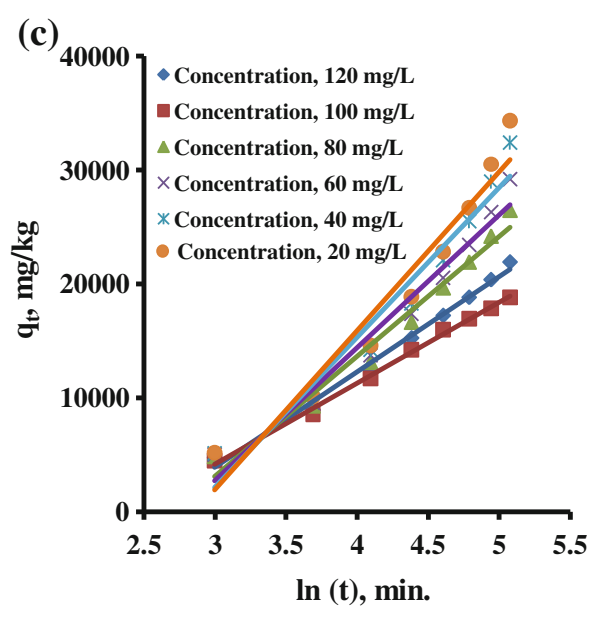

Elovich kinetic model

(d)

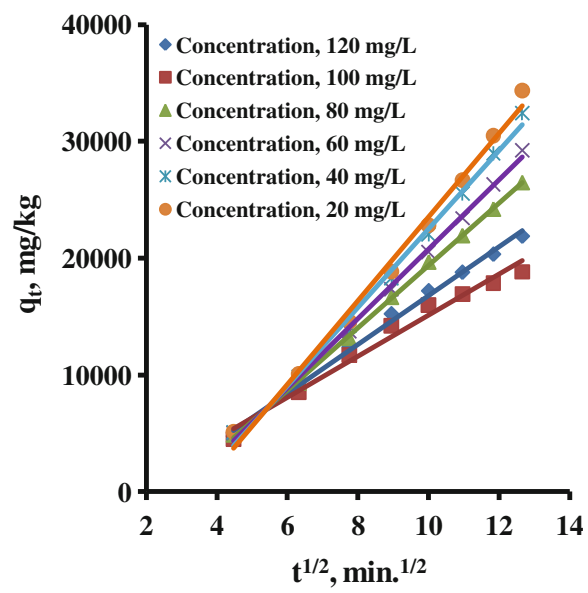

Intraparticle diffusion kinetic model correlation was developed between two variables and that the values vary from 0.952 to 0.993 . Further, a value of $k_{\mathrm{p}}$ for the interapartical kinetic model for COD varies from $4,290.6$ to $8,782.6$ and $R^{2}$ value varies from 0.923 to 0.965 (Fig. 7d).

From Fig. 8a, it may be found that the pseudo first-order rate constant $\mathrm{k}_{1}$ for TDS ranges between 0.009 and $0.013 \mathrm{~min}^{-1}$. The correlation coefficient $R^{2}$ was found to range from 0.929 to 0.949 . It was found that the values for rate constant $\left(k_{2}\right)$ of pseudo-second order kinetic model for TDS decreases from 0.0023 to $0.0051 \mathrm{~kg} \mathrm{mg}^{-1} \mathrm{~min}^{-1}$ (Fig. 8b) and the ' $\beta$ ' value for TDS varies between 0.000076 and 0.000141 with an increase of the initial concentrations from 20 to $120 \mathrm{mg} \mathrm{L}^{-1}$ (Fig. 8c). The correlation coefficient $R^{2}$ for pseudo-second order model varies from 0.931 to 0.978 and correlation coefficient $R^{2}$ for Elovich kinetic model showed that very high correlation was developed between two variables, and the values vary from 0.963 to 0.996 . Further, a value of $k_{\mathrm{p}}$ for the interapartical kinetic model for TDS varies from 1,759.3 to $3,363.5$ and $R^{2}$ value varies from 0.959 to 0.977 (Fig. $8 \mathrm{~d}$ ).

The summary of regression equations and $R^{2}$ for COD and TDS removal obtained at an initial concentration of $100 \mathrm{mg} \mathrm{L}^{-1}$ (higher adsorption capacity of COD and TDS in a municipal solid waste leachate has found at an initial concentration of $100 \mathrm{mgL}^{-1}$ ) are given in Table 3 . From Table 3, it may be found that equilibrium (kinetic) data found fitted well with Elovich kinetic model $\left(R^{2}=0.993\right.$ for COD and $R^{2}=0.996$ for TDS) than that of other models.

Results from Figs. 7 and 8 and from Table 3 indicate that equilibrium COD and TDS data fitted well with Elovich kinetic model than that of other models. Thus, the study informed that Elovich kinetic model was used to elucidate the mechanism of COD and TDS adsorption in a municipal solid waste leachate using $M$. oleifera seed as a coagulant and is useful for design and optimization of COD and TDS removal treatment processes. 
Table 3 The regression equations and $R^{2}$ for COD and TDS removal obtained at an initial concentration of $100 \mathrm{mg} \mathrm{L}^{-1}$

\begin{tabular}{|c|c|c|c|c|}
\hline \multirow[t]{3}{*}{ Models } & \multicolumn{4}{|l|}{ Parameters } \\
\hline & \multicolumn{2}{|l|}{ COD } & \multicolumn{2}{|l|}{ TDS } \\
\hline & Regression equation & $R^{2}$ & Regression equation & $R^{2}$ \\
\hline $\begin{array}{l}\text { Pseudo first-order } \\
\text { kinetic model }\end{array}$ & $Y=0.0108994 X+3.1457$ & 0.946 & $Y=0.00976268 X+2.9732$ & 0.949 \\
\hline $\begin{array}{l}\text { Pseudo-second order } \\
\text { kinetic model }\end{array}$ & $Y=1.24548 \times 10^{-5} X+0.0014$ & 0.963 & $Y=3.00673 \times 10^{-5} X+0.0035$ & 0.978 \\
\hline $\begin{array}{l}\text { Elovich } \\
\text { kinetic model }\end{array}$ & $Y=1,7384.5 X-41,540.70$ & 0.993 & $Y=7,093.34 X-17,092.10$ & 0.996 \\
\hline $\begin{array}{l}\text { Interapartical } \\
\text { kinetic model }\end{array}$ & $Y=4,290 X-5,521.74$ & 0.965 & $Y=1,759.04 X-2,473.81$ & 0.977 \\
\hline
\end{tabular}

The adsorption capacity of $M$. oleifera of this study has been verified with the adsorption capacity of M. oleifera of previous investigators. Asrafuzzaman et al. (2011) found that the maximum reduction of total coliform counts $(\mathrm{cfu} / 100 \mathrm{~mL})$ and turbidity using $100 \mathrm{mg} \mathrm{L}^{-1}$ M. oleifera was 96.00 and $94.10 \%$, respectively. After $24 \mathrm{~h}$ of settling time, maximum removal efficiency achieved by $M$. oleifera seed coagulant was $96.34 \%$ for turbidity, $88.89 \%$ for color and $26.50 \%$ for total suspended solids in an aqueous solution (Nwaiwu and Lingmu 2011). Nwaiwu and Lingmu 2011 achieved $94.56 \%$ of microbial population removal. Sarah and Susan 2011 achieved $90.00 \%$ of bacterial removal using $M$. oleifera coagulant in an aqueous solution. The results of Katayon et al. (2004, 2005, 2006a) and Muyibi and Evison (1995b) indicated that $M$. oleifera seed extract may not be an efficient coagulant for low turbid water. However, the extract of M. oleifera seed was used to reduce the hardness to $70.00 \%$ as well as turbidity to $99.00 \%$ in hard water (Muyibi and Evison 1995a). Furthermore, the extract efficiency of $M$. oleifera seed for turbidity removal equals that of alum according to the study conducted by Muyibi and Alfugara (2003). The same observations were also made by Yarahmadi et al. (2009). The concentration reduction obtained for a concentration of $10 \mathrm{~g} \mathrm{~L}^{-1}$ of $M$. Oleifera seed kernels powder has similar effect as that of conventional coagulum and alum (Amagloh and Benang 2009). The maximum removal percentage of lead in an aqueous solution was found to be $48.40 \%$ with 180 min contact time using ground $M$. oleifera pods (Adelaja et al. 2011) and $97.00 \%$ of the algae present in the raw Nile water were removed (Shehata et al. 2002) using M. oleifera coagulant.

Salwa et al. (2011) conducted the experiments to remove color from a landfill leachate. Without addition of $\mathrm{ZnO}$, color removal of $88.80 \%$ was achieved at the $\mathrm{pH}$ of
5 and at a contact time of $90 \mathrm{~min}$, and with the addition of $0.2 \mathrm{~g}$ of $\mathrm{ZnO}$ gave the highest color removal of $90.10 \%$ at $60 \mathrm{~min}$ from a landfill leachate (Salwa et al. 2011). Corneliu et al. (2010) has studied the sorption of $\mathrm{Cu}$ in a leachate using moss peat as biosorbent. The results indicated that a removal rate of $\mathrm{Cu}$ was $95.00 \%$ (Corneliu et al. 2010). The adsorption of $\mathrm{Cu}, \mathrm{Zn}$ and $\mathrm{Fe}$ reached the maximum removal condition after $5 \mathrm{~h}$ with a removal efficiency of $41.29,58.94$ and $52.03 \%$, respectively, by dead fungal biomass from a landfill leachate (Abdullah et al. 2011).

In general, the costs of activated carbon prepared from biomaterials are negligible when compared with the cost of commercial activated carbon (Nigam and Rama 2002). Further, the cost of this natural coagulant would be less expensive compared with the conventional coagulant (alum) for water and wastewater purification (Okuda et al. 1999, 2001; Broin et al. 2002) since it is available in most rural communities (Gideon and Richardson 2010). Because of the abundance source, low price, multi-purposes, biodegradation properties (Yarahmadi et al. 2009; Sharma et al. 2006; Katayon et al. 2005), better coagulation properties (Nwaiwu and Bello 2011) and antimicrobial properties (Amagloh and Benang 2009), M. oleifera can be encouraged to use in water and wastewater purification purposes. Definitely, this coagulant process using $M$. oleifera is likely to reduce the high cost of the current water and wastewater treatment systems.

\section{Conclusion}

Adsorption of COD and TDS by $M$. oleifera seed coagulant was influenced by $\mathrm{pH}$ and temperature. The maximum removal of COD and TDS in a leachate occurred at an 
optimum pH of 7 and an optimum temperature of $318 \mathrm{~K}$. In order to validate the effects of $\mathrm{pH}$ and temperature on COD and TDS removal in a leachate; experiments have been performed by changing the initial coagulant concentration, by keeping constant optimum $\mathrm{pH}$ (7) and by keeping constant optimum temperature $(318 \mathrm{~K})$. The experimental data were also fitted to various kinetic models viz., pseudo first-order, pseudo second-order, Elovich and intraparticle diffusion models. The results of the present study indicated that the adsorption capacity of $M$. oleifera coagulant for removing COD and TDS in the municipal solid waste leachate increased with increasing of initial concentration (20-120 mg L ${ }^{-1}$ ). It could be found that adsorption of COD and TDS by $M$. oleifera coagulant occurred very rapidly within the first $20 \mathrm{~min}$ and equilibrium occurred at $120 \mathrm{~min}$. Further, the maximum adsorption by the M. oleifera seed coagulant for removing COD and TDS in a leachate was 84.5 and $82.6 \%$, respectively, and obtained at an optimum dosage of $100 \mathrm{mg} \mathrm{L}^{-1}$. Based on the results obtained from the kinetic models, the equilibrium data were best fitted with the Elovich kinetic model than that of other models, because Elovich kinetic model at different physico-chemical conditions showed very high correlation coefficients $\left(R^{2}=0.993\right.$ for $\mathrm{COD}$ and $R^{2}=0.996$ for TDS). Thus, the results of this study indicate that use of M. oleifera coagulant for removing COD and TDS in a municipal solid waste leachate seems to be an economical and worthwhile alternative over other conventional methods, because of their abundant source, low price, multi-purposes, biodegradation, better coagulation and antimicrobial properties.

Acknowledgments The work described in this paper was carried out in the Environmental Engineering Laboratory, Department of Civil Engineering at Easwari Engineering College, Anna University, Chennai, Tamil Nadu, India. The author is indebted to Management for providing all necessary facilities to carryout the experimentsand to all staff members for helping to carryout the experiments.

\section{References}

Abdullah AM, Zahangir AM, Nik ANM, Amirul NM, Shah SR (2011) Adsorption of heavy metal from landfill leachate by wasted biosolids. Afr J Biotechnol 10(81):18869-18881

Adelaja OA, Amoo IA, Aderibigbe AD (2011) Biosorption of Lead (II) ions from aqueous solution using Moringa oleifera pods. Archives Appl Sci Res 3(6):50-60

Adinata D, Wan Daud WM, Aroua MK (2007) Preparation and characterization of activated carbon from palm shell by chemical activation with $\mathrm{K}_{2} \mathrm{CO}_{3}$. Bioresour Technol 98(1):145-149

Aiyesanmi AF, Imoisi OB (2011) Understanding leaching behaviour of landfill leachate in Benin-city, Edo State, Nigeria through Dumpsite Monitoring. British J Environ Clim Change 1(4): 190-200
Akhtar M, Hasany SM, Bhanger MI, Iqbal S (2007a) Low cost sorbents for the removal of methyl parathion pesticide from aqueous solutions. Chemosphere 66:1829-1838

Akhtar M, Hasany SM, Bhanger MI, Iqbal S (2007b) Sorption potential of Moringa oleifera pods for the removal of organic pollutants from aqueous solutions. J Hazard Mater 141:546-545

Amagloh FK, Benang A (2009) Effectiveness of Moringa oleifera seed as coagulant for water purification. Afr $\mathbf{J}$ Agric Res 4(1):119-123

Amir HM, Ali AR (2011) Survey on the effect of landfill leachate of shahrood city of Iran on ground water quality. J Appl Technol Environ Sanitation 1(1):17-25

APPA, AWWA and WEF (2005) Standard methods for the examination of water and wastewater, 21th edn. American Public Health Association, Washington D.C.

Aravind KS, Prem NT (2003) Removal of basic dye from industrial wastewater. Ind J Chem Tech 10:211-216

Asrafuzzaman M, Fakhruddin ANM, Alamgir HM (2011) Reduction of turbidity of water using locally available natural coagulants. ISRN Microbiol 2011:1-6

Azim M, Mahabubur RM, Riaz HK, Kamal ATMM (2011) Characteristics of leachate generated at landfill sites and probable risks of surface and groundwater pollution in the surrounding areas : a case study of Matuail landfill site, DHAKA. J Bangladesh Acad Sci 35(2):153-160

Babel S, Kurniawan TA (2003) Low-cost adsorbents for heavy metals uptake from contaminated water: a review. J Hazard Mater B97:219-243

Beltrán-Heredia J, Sánchez-Martín J (2008) Heavy metals removal from surface water with Moringa oleifera seed extract as flocculant agent. Fres Environ Bull 17(12A):2134-2140

Beltrán-Heredia J, Sánchez-Martín J (2009) Removal of sodium lauryl sulphate by coagulation/flocculation with Moringa oleifera seed extract. J Hazard Mater 164:713-719

Boucher J, Steiner L, Marison IW (2007) Bio-sorption of atrazine in the press-cake from oilseeds. Water Res 41:3209-3216

Broin M, Santaella C, Cuine S, Kokou K, Peltier G, Joel T (2002) Flocculant activity of a recombinant protein from Moringa oleifera lam. seed. Appl Microbiol Biotechno 60:114-119

Caceres A (1991) Pharmacological properties of Moringa oleifera preliminary screening for antimicrobial activity. J Ethnopharmacol 33:213-220

Corneliu P, Igor C, Marius SS, Carmen P, Lavinia T, Matei M (2010) Integrated treatment of leachate from municipal waste solid landfill. Environ Eng Manag J 9(1):95-100

Daniyan SY, Abalaka ME, Eru EO (2011) The use of Moringa seed extract in water purification. IJRAP 2(4):1265-1271

Demetracopoulos AC, Korfiatis GP, Bourodimos EL, Nawy EG (1984) Modeling for design of landfill bottom liner. J Environ Eng Proc ASCE 110(6):1084-1098

Gideon S, Richardson CP (2010) Coagulation efficiency of Moringa oleifera for removal of turbidity and reduction of total coliform as compared to aluminum sulfate. Afr J Agric Res 5(21): 2939-2944

Gopal R, Rao ASR (2009) Basic and applied soil mechanics. New Age International (P) Ltd., New Delhi

Ho YS, McKay G (1998) A comparison of chemisorption kinetic models applied to pollutant removal on various sorbents. Trans Chem 76:332-340

Igwe JC, Abia AA (2006) A bioseparation process for removing heavy metals from waste water using biosorbents. Afr J Biotechnol 5(12):1167-1179

Jahn SA (1988) Using Moringa seeds as coagulants in developing countries. J AWWA 80:43-50 
Jahn SA, Musnad HA, Burgstaller H (1986) The tree that purifies water: cultivating multipurpose Moringaceae in the Sudan. Unasylva 38(2):23-28

Karfiatis GP, Demetracopoulos AC (1984) "Moisture transport in a solid waste column". J Environ Eng Proc ASCE 110(4):780-796

Katayon S, Magat Mohd Noor MJ, Asma M, Thamer AM, Liew Abdullah AG, Idris A, Suleyman AM, Aminuddin MB, Khor BC (2004) Effect of storage duration and temperature of Moringa oleifera stock solution on its performance in coagulation. Int $\mathbf{J}$ Eng Technol 1:146-151

Katayon S, Megat MN, Asma M, Ghani LAA, Suleyman AM (2005) Effect of storage conditions of Moring olifera seeds on its performance in coagulation. J Biores Technol 97(13):14551460

Katayon S, Magat Mohd Noor MJ, Asma M, Abdul Ghani LA, Thamer AM, Azni I, Ahmad J, Khor BC, Suleyman AM (2006a) Effect of storage conditions of Moringa oleifera seed on its performance in coagulation. Bioresour Technol 97:1455-1460

Katayon S, Ng SC, Magat Johari MMN, Abdul Ghani LA (2006b) Preservation of coagulation efficiency of Moringa oleifera, a natural coagulant. Biotech Bioprocess Eng 11:489-495

Matthew CM, Chukwuka IN, Ikechukwu N, Chinenye AO, Okechukwu DO (2011) Factorial optimization and kinetics of coal washery effluent coag-flocculation by Moringa oleifera seed. Biomass Adv Chem Eng Sci 1:125-132

Maximova A, Koumanova B (2008) Equilibrium and kinetics study of adsorption of basic dyes on to perfil from aqueous solution. J Univ Chem Technol Metallurgy 43(1):101-108

Miquel L, Wendy B (2010) Anti-cyanobacterial activity of Moringa oleifera seeds. J Appl Phycol 22:503-510

Mishra SH, Mani D (1993) Pollution through solid waste. Ashish Publishing House, New Delhi

Muyibi S, Alfugara MS (2003) Treatment of surface water with Moringa oleifera seed extract and alum- a comparative study using a pilot scale water treatment plant. Int J Environ Stud 60(6):617-626

Muyibi SA, Evison LM (1995a) Moringa oleifera seeds for softening hard water. Water Res 29(4):1099-1105

Muyibi SA, Evison LM (1995b) Coagulation of turbid waters and softening hardwater with Moringa oleifera seeds. Int J Environ Stud 49:247-259

Muyibi SA, Hazalizah H, Irmayanti I, Megat JMMN (2001) Coagulation of river water with Moringa oleifera seeds and alum a comparative study. J Inst Eng Malays 62(2):15-21

Muyibi SA, Megat JMMN, Lam HN, Tan KL (2002) Effects of oil extraction from Moringa oleifera seeds on coagulation of turbid water. Environ Stud 59(2):243-254

Ndabigengesere A, Narasiah KS (1998a) Quality of water treated by coagulation using Moringa oleifera seeds. Water Res 32:781-791

Ndabigengesere A, Narasiah KS (1998b) Use of Moringa oleifera seed as a primary coagulant in wastewater treatment. Environ Tech 19:789-800

Ndabigengesere A, Narasiah KS, Talbot BG (1995) Active agent and mechanism of coagulation of turbid waters using Moringa oleifera. Water Res 29(2):703-710

Nigam A, Rama OP (2002) Corncob-A promising adsorbent for the removal of chromium (VI) from wastewater. Indian J Environ Prot 22(5):550-553

Noor AZ, Hamidi BAZ, Mohamad SY (2011) Coagulation and flocculation process of landfill leachate in removing COD, color and ammonia using polyaluminum chloride (PACI). In: Empowering Science, Technology and Innovation Towards a Better Tomorrow, UTMAS 2011, paper no EO26, vol 26, pp 109-115. http://www.umt.edu.my/dokumen/UMTAS2011/ENG/Oral_ENG/ EO26_AINEE.pdf
Nwaiwu NE, Bello AA (2011) Effect of Moringa oleifera-alum ratios on surface water treatment in north east Nigeria. Res J Appl Sci Eng Technol 3(6):505-512

Nwaiwu NE, Lingmu B (2011) Effect of settling time on turbidity removal using Moringa oleifera seed powder. Ozean J Appl Sci 4(3): 195-208

Okuda T, Baes AU, Nishijima W, Okada M (1999) Improvement of extraction method of coagulation active components from Moringa oleifera seed. Water Res 33(15):3373-3378

Okuda T, Baes AU, Nishijima W, Okada M (2001) Isolation and characterisation of coagulant extracted from Moringa oleifera seed by salt solution. Water Res 35(2):405-410

Olsen A (1987) Low technology water purification by bentonite clay and Moringa oleifera seeds flocculation as performed in sudanese village: effects of Schistosoma Mansoni cericariae. Water Res 21:81-92

Oluduro AO, Aderiye BI (2007) Impact of Moringa seed extract on the physicochemical properties of surface and undergroundwater. Int J Biol Chem 1(4):244-249

Parimalam R, Raj V, Sivakumar P (2011) Adsorption isotherms, kinetics, thermodynamics and desorption studies of reactive Orange 16 on activated carbon derived from Ananas comosus (L.) carbon. Arpn J Eng Appl Sci 6(11):15-26

Peter K, Morton AB, Alix PR, Anders B, Anna L, Thomas HC (2002) Present and long-term composition of MSW landfill leachate: a review. Crit Rev Environ Sci Technol 32(4):297-336

Pollard SJT, Thompson FE, McConnachie GL (1995) Microporous carbons from Moringa oleifera husks for water purification in less developed countries. Water Res 29:337-347

Ramachandran C, Peter KV, Gopalakrishnan PK (1980) Drumstick (Moringa oleifera) a multipurpose Indian vegetable. Econ Bot 34(3):276-283

Salwa MZM, Mahyun AW, Mohammad TS, Norsyazwani CM (2011) Landfill leachate treatment by a coagulation-photocatalytic process. IPCBEE 12:224-228

Sánchez-Martín J, Ghebremichael K, Beltrán-Heredia J (2010) Comparison of single-step and two-step purified coagulants from Moringa oleifera seed for turbidity and DOC removal. Bioresour Technol 101:6259-6261

Sarah AW, Susans AA (2011) Impact of a natural coagulant pretreatment for colour removal on solar water disinfection (SODIS). J Water Sanitation Hygiene Dev 1(1):57-67

Saulawa SB, Ajibike MA, Igboro SB, Lukman S, Ibrahim FB, Abubakar UA (2011) Minimising the deterioration of the properties of Moringa oleifera seed extract using Trona solution. Int J Water Res Environ Eng 3(12):298-302

Sharma P, Kumari P, Srivastava MM, Srivastava S (2006) Removal of cadmium from aqueous system by shelled Moringa oleifera Lam. Seed powder. Biores Technol 97(2):299-305

Shehata S, Badr S, Wahba S (2002) Drinking water treatment options for eliminating freshwater algae. Int $\mathrm{J}$ Environ Stud 59:679-688

Sivakumar D and Pushpakaran P (2010a). Effectiveness of Moringa oleifera seed to treat a municipal solid waste leachate-Part I. Proceedings of National conference on Environmental Pollution, pp 250-257

Sivakumar D and Pushpakaran P (2010b) Kunetic models study on municipal solid waste leachate using Moringa oleifera seedPart II. Proceedings of National conference on Environmental Pollution, pp 258-268

Słomczyńska B, Słomczyński T (2004) Physico-chemical and toxicological characteristics of leachates from MSW landfills. Pol J Environ Stud 13(6):627-637

Tchobanoglous G, Theisen H and Vigil SA (1993a) Integrated solid waste management: engineering principles and management 
issues. McGraw Hill International editions, Civil Engineering series, McGraw Hill Inc., Singapore

Tchobanoglous G, Theisen H, Eliassen R (1993b) Solid waste engineering principles and management issues. McGraw-hill Book Company, New York

Varsha P, Punita P (2010) A preliminary study on Coccinia indica fruit mucilage extract as coagulant-flocculent for turbid water treatment. J Pure Appl Sci 18:27-30
Yarahmadi M, Hossieni M, Bina B, Mahmoudian MH, Naimabadie A, Shahsavani A (2009) Application of Moringa oleifera seed extract and poly aluminium chloride in water treatment. J World Appl Sci 7(8):962-967 